\title{
The British and French Associations at Havre.
}

IN connexion with the annual congress of L'Association Française pour l'Avancement des Sciences, held at Havre towards the end of July, the members of the British Association not taking part in the South Africa meeting were invited to attend. In addition, facilities were given for the Conference of Delegates from Corresponding Societies of the British Association to be held, the president for the meeting being Dr. F. A. Bather. Sir Henry Lyons and Mr. T. Sheppard were elected by the Council officially to represent the British Association, and in the absence of Dr. Tierney, Mr. Sheppard acted as secretary for the Conference for the Havre meeting.

The French Association, though on a smaller scale, is organised on similar lines to that of the British Association, and has its sections, though the numbers attending the sectional meetings suggest that probably papers of more general interest to a larger audience would have been more desirable to the French Association in view of its present membership.

Our French confrères issued a Bulletin in connexion with the Association's fifty-eighth year, containing various items of information; also a journal with particulars of the excursions, list of officers, etc. A volume entitled "Le Havre", and another "Normandy", were presented to each delegate, and facilities for visiting different places were given.

The sections were devoted to mechanics, astronomy, geodesy, mathematics, navigation, aeronautics, civil and military engineering, physies, physical and general meteorology, geology and mineralogy, botany, anthropology, medical sciences, radiology and medical electrology, pharmaceutical sciences, experimental psychology, biogeography, agronomy, geography, political and statistical economy, pedagogy, hygiene and public health. In addition to papers read under these various headings there were conferences on " Le Problème de l'Hérédité tuberculeuse", and "L'Orientation professionnelle et l'Apprentissage". Excursions were arranged to Honfleur. Sunday was devoted to an excursion to Fécamp, where a monument to Dr. Leon Dufour was unveiled, and at the conclusion of the meeting excursions were made to Grouville, Lisieux, Caen, Bayeux, Mont St. Michel; and to Rouen and its neighbourhood.

The conference commenced with the presidental address of General Perrier, and in the evening a reception was given by the Municipality of Havre at the Hotel de Ville. There was a visit to the port, showing its facilities for dealing with traffic, and the members were shown round one of the large liners. There was an official visit to the Museum at Havre, the specimens being described by the Curator, Dr. Loir ; also a ceremony at the French War Memorial, when a wreath was placed thereon by Sir Henry Lyons on behalf of the British Association, and another at the cemetery occupied by English soldiers, when General Perrier presented a wreath on behalf of the French Association.

With regard to the British section, rooms had been placed at the disposal of the Conference of Delegates in the Hôtel des Sociétés Savantes. This was originally intended to be the meeting place of the Conference of Delegates, but on account of the difficulty in darkening the rooms the actual conference was held at the Lycée de Garçons. In the former rooms, however, were exhibited a collection of photographs of archæological interest taken from the air, kindly lent by Mr. O. G. S. Crawford of the Ordnance Survey, and a representative series of maps illustrating regional survey, showing various aspects of the Croydon district, kindly supplied by Mr. C. C. Fagg. The room was also decorated with a selection of the British Association banners which were sent at the special request of our French friends. The banners had been selected on account of their historical interest, and were as follows: York 1831, Edinburgh 1850, Aberdeen 1859, Bath 1864, Norwich 1868, Liverpool 1870, Edinburgh 1871, Montreal 1884, Liverpool 1896, Bristol 1898, Manchester 1915.

There were nearly a hundred representatives at the Conference of Delegates, including both French and English members. Dr. Bather was in the chair, and there were delegates from fifteen British societies. The chairman regretted the death during the year of Sir George Fordham, who was well known in Havre, and had originally been proposed as president for the Conference. The chairman then called upon Mr. T. Sheppard, who referred to the assistance received from Dr. A. Loir at the previous conference at Havre in 1914, and to the honour conferred upon Dr. Loir by the University of Glasgow at the British Association meeting last year, when he received the degree of doctor of law, and Mr. Sheppard asked Dr. Loir to accept on behalf of some of his friends, members of the British Association, the cap, hood, and gown which he was entitled to wear. Dr. Loir returned suitable thanks for the mark of esteem.

On the suggestion of the French Association, the principal subject for discussion at the Conference was the scientific aspects of the Channel tunnel, a paper illustrated with slides being read by Mr. E. O. ForsterBrown on the subject. After carefully reviewing the question, Mr. Forster-Brown concluded that : (1) The existing geological evidence is favourable; (2) further geological evidence should be secured preparatory to designing the work and estimating its cost ; (3) the construction of the tunnel is likely to result not only in material benefit to the parties constructing it, but it will strengthen still further the amicable relations existing between England and France. Mr. Forster-Brown's paper appears in extenso in the Colliery Guardian of Aug. 16 and 23.

A communication was received from Prof. P. F. Kendall, the last survivor of the many British geologists who in the eighties of the last century were consulted as to the possibility of a tunnel under the Channel. Prof. Kendall has kept in touch with the subject, and his observations were made partly in the way of encouragement and partly as a warning. Having reviewed the percentage of days of rough weather on the Channel, and the questions of air transport, a train ferry, and a bridge, respectively, he concluded that a tunnel seems to be the only form of transit likely to be satisfactory. $\mathrm{He}$ is satisfied that the engineers will be able to overcome any difficulties provided they keep in touch with the geologists, who have a knowledge of the strata and the peculiar conditions which obtain. Prof. Kendall urged further soundings. He pointed out that "On the English side the official geological map is at present undergoing revision, during which it may be expected that attention will be paid to the tectonic structure. The existing map, however, shows that the Cretaceous rocks are subject to such changes of level between the coast at Folkestone and the great breach of the escarpment at Wye as to show that it must be affected by considerable folds; not only so, but at Beachborough, 5 miles from the coast, a fault occurs which completely severs the Gault outcrop and must consequently have a displacement of more than 100 feet. There is no reason, as far as can be seen, why the 30 miles of submarine outcrop should differ materially

No. 3122, VoL. 124] 
from comparable lengths of outcrop in France and England respectively, and it behoves those upon whom the duty falls of laying down the line of the tunnel, to take these probabilities into account." Generally speaking, Prof. Kendall seemed to think that there are more difficulties than had been assumed by most of his predecessors, but that they are not unsurmountable, and in any case he is strongly opposed to the suggestion that a tunnel might be made in the Gault under the chalk. This paper will appear in extenso in the Naturalist.

Afterwards the chairman, Dr. Bather, addressed the delegates as to the value of their annual conference and asked for opinions to be expressed with regard to its future working. He called upon Mr. T. Sheppard, the vice-chairman of the Corresponding Societies' Committee, who has been associated with the Conference for many years, to give his views on the matter, after which many of the delegates spoke.

At the final session of the French Association, under the presidency of General Perrier, medals which had been specially struck were presented to those who had been conspicuous in assisting the Congress, the names of the recipients being in relief. Sir Henry Lyons, director of the Science Museum, London, and Mr. T. Sheppard, who acted as local secretary for the Havre meeting on behalf of the British Association, each received one of these medals.

At the concluding banquet, held at the Hotel Frascati, representatives of the different countries sending delegates were 'toasted ', and members from Belgium, Portugal, Spain, and Great Britain each spoke in turn, Mr. Sheppard representing the British Association.

\section{Welsh Bygones.}

$\mathrm{T} N$ view of the plea for the institution of a national folk-museum for England which appeared in NATURE of Aug. 24, p. 289, it may not be out of place to describe here briefly what has already been done in the National Museum of Wales at Cardiff on similar lines to preserve the evidences of the arts and industries of the Welsh people in post-Reformation times.

The collections for the most part are at present housed temporarily in a gallery which was specially built for the purpose in 1925; but adequate and permanent accommodation will be available when the eastern range of galleries now in course of erection is completed. At the moment 1294 objects are actually on exhibition, but a number are still in store. The exhibits cover a very wide range; and they also include a certain amount of material from England and Ireland. This has been judged necessary not only for purposes of comparison, but also because England for centuries has supplied Wales with such articles as her pottery and most of her cutlery. Many of the articles are dated, and thus, in illustrating the history of the arts and crafts in Wales, they also provide a basis for a systematic chronology for Welsh bygones.

The arrangement of the exhibits has been carried out so far as possible with due regard to their original purpose, but the limited space available makes complete logical arrangement difficult and in some cases impossible. So far as may be, groups have been kept together. Thus, on passing from the entrance hall of the Museum, where are the Eisteddfod chairs, the stocks, pottery, folklore objects and other exhibits of special interest, the first cases in the Bygones Gallery contains kitchen appliances, followed by table ware and then laundry appliances. Then comes a block of exhibits showing dairy appliances and agricultural implements. These are succeeded by the implements and appliances of various industries, such as mining, spinning and weaving, lacemaking and knitting, trapping and fishing and transport. Then follow exhibits relating to the horse and the various crafts. Furniture, costumes and personal ornaments, important sections, necessarily occupy a considerable amount of space. The ecclesiastical, economic, and social life are well illustrated by a varied and wide range of objects. Dress, in particular, includes a valuable collection of richly ornamented eighteenth-century costumes from Tredegar Park. These, of course, are additional to the well - represented peasants' costumes. Objects related to the Eisteddfod naturally figure largely. They include manuscripts, Druid's chairs, and the 'wooden book'-squared wooden sticks in a frame, invented by the Glamorgan druids-harps, etc., and other musical instruments.

Among the objects illustrative of Welsh folklore are rags from wishing wells and a large and valuable collection of 'love-spoons'. The 'love spoon', it may be explained, was a carved wooden spoon which was presented by the lover to the object of his affections. Originally it was merely a wooden copy of a metal spoon, but it became highly elaborated. Another folklore object of great interest which the Museum is fortunate enough to possess is a "Mari Llwyd' from Llangwynyd, Glamorgan. The 'Mari Llwyd ' corresponds to the "hooden horse' of 'Thanet and elsewhere. The 'Mari Llwyd', like the 'hooden horse ', is a horse's skull and jaws sheeted and adorned with coloured ribbon, streamers, etc. The sheet completely covered a man who carried it at the head of a procession at the Christmas and New Year festivities. In Wales its use was afterwards transferred to May Day. It would be out of place to discuss its origin and meaning here; but though the authorities of the National Museum accept the derivation that it was a substitute for the ass of the medieval miracle and mystery plays, it is more probably a fertility symbol of much older date.

Owing to considerations of space, the collections with two exceptions have to be exhibited under museum conditions, that is, in cases and on walls. The exceptions are the kitchen and bedroom furniture and appliances. Two recesses in the galleries have been utilised to give these objects their natural setting in a typical Welsh kitchen and a typical Welsh bedroom. Here are the fireplace, turnspit, cooking utensils, dressers with crockery, clocks, chairs, etc., the bed, mattress and bedding, the coffer, press, Bible and deed boxes, candles and so forth, in the conditions in which they were actually in use.

A well-illustrated guide to the collections, with an introductory account of Welsh life and culture by Mr. Iorwerth C. Peate, assistant curator, has recently been published by the National Museum of Wales, Cardiff (price 1s. 6d.).

\section{University and Educational Intelligence.}

CAmbridge.-The Appointments Committee of the Faculty of Agriculture and Forestry has appointed Mr. F. H. Garner, of Clare College, to be University lecturer in agriculture, and Mr. A. S. Watt to be University lecturer (Gurney lecturer) in forestry.

The following University lecturers have resigned their offices: Mr. P. Sergeant Florence, Caius (economics); Mr. S. Lees, St. John's (engineering); Mr. R. V. Southwell, Trinity (mathematics); Dr. D. R. Hartree, St. John's (physics); Mr. A. Amos, Downing (agriculture); Mr. R. L. Manning, Jesus (geography). 